\title{
電極表面連続研磨器具付き白金電極を用いる 水溶液酸化還元電位の安定測定
}

\author{
井岡聖一郎 ${ }^{\circledR 1}$, 岩月 輝希 ${ }^{1}$, 加藤 修 $^{2}$, 今 北 毅 ${ }^{3}$
}

\section{1 緒言}

我が国では原子力発電により発生する高レベル放射性廃 棄物を，炭素鋼やベントナイトなどから成る人工バリアと 地下深部に扔ける岩盤の特性（非常に遅い地下水流速や還 元環境等）を利用した天然バリアを組み合わせた地層処分 システムにより隔離することが計画されている．放射性核 種や金属元素の溶解度や収着特性は, 地下水の酸化還元状 態に影響を受ける ${ }^{1 / 2)}$ 。そのため，地層処分の安全評価を 実施する際に地下深部における酸化還元状態を評価する方 法が必要である，その一つとして，地下水の酸化還元電位 (Eh）の測定が挙げられる ${ }^{3}$.

この地下水の $\mathrm{Eh}$ 測定に関しては, 幾つかの問題点が指 摘されている. 例えば, 溶液系内の酸化還元反応の非平 衡 ${ }^{45)}$ や, 電極表面への電気化学的に活性あるいは不活性 な物質の吸着等による電極一溶液間の電気化学的環境の変 化(6) 8) な゙がある. そのため, 地下水の $\mathrm{Eh}$ 測定が, 地下 の酸化還元状態を評価するための手法として不適切な場 合 ${ }^{9}$ や，安定した地下水の $\mathrm{Eh}$ の值を取得するのに長時間 の観測が要求される場合 ${ }^{10}$ がある.

著者らは, これまでに岐阜県東濃地域に扔いて, 深度約 $750 \mathrm{~m}$ の地下水を対象として $\mathrm{pH}$ や $\mathrm{Eh}$ 等の物理化学パラ メーターを測定している（Fig. 1)。測定には，電極法に よる測定機器 ${ }^{11}$ を使用した。 その結果, 地下水の $\mathrm{pH}$ や電 気伝導度（EC）は約 1500 分（約 1 日）で安定するが, Eh が安定した值に達するのには約 4500 分（約 3 日）を 要し, 長期間の観測が必要であることが経験的に分かって いる. 測定を行った地下水の滞留時間は, 数千年オーダー と非常に長く，それと比較して自然状態での酸化還元反応 が平衡に達するのに要する時間は短いと考えられることか ら, Eh の測定に長時間要する理由としては, 前述したよ うに，電極表面への電気化学的に活性あるいは不活性な物

\footnotetext{
${ }^{1}$ 日本原子力研究開発機構地層処分研究開発部門東濃地科学研究 ユニット：509-6132 岐阜県瑞浪市明世町山之内 1-64

2 株式会社神戸製鋼所機械エンジニアリングカンパニーエンジニ アリング事業部：657-0845 兵庫県神戸市灘区岩屋中町 4-2-7 ${ }^{3}$ 株式会社コベルコ科研技術本部環境事業部: 651-2271 兵庫県 神戸市西区高塚台 1-5-5
}

質の吸着等による電極-溶液間の電気化学的環境の変化の 可能性が挙げられる.

電極表面の電気化学的環境の変化にかかわる問題につい ては，不活性条件下で Eh 測定用の白金電極表面を物理的 に研磨（サンドパーパー＃180 使用）することにより， 白金電極表面に形成していると考えられる酸化皮膜等を除 去し，還元的な地下水（鉄及び硫黄の化学種の酸化還元反 応により地下水の $\mathrm{Eh}$ が決まっていると考えられる地下 水）の $\mathrm{Eh}$ の迅速な測定が可能であることが報告されてい $3^{12)}$. しかしながら, この例では, 白金電極表面の物理的
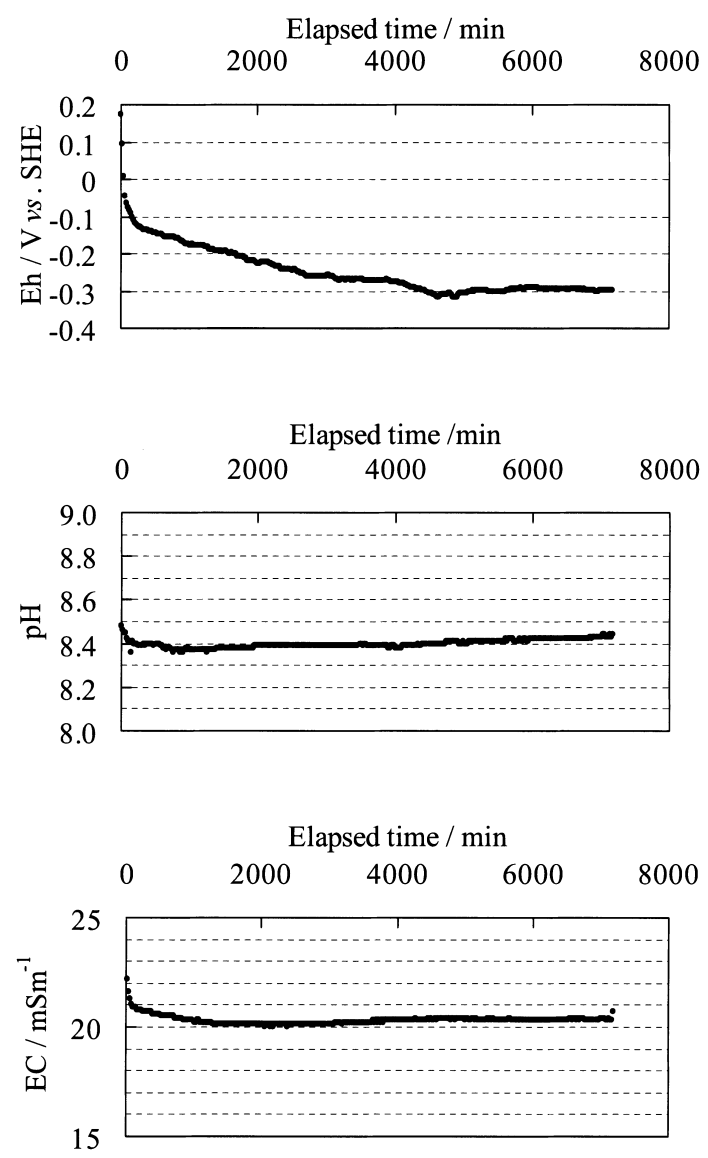

Fig. 1 Long-term continuous measurements of Eh, $\mathrm{pH}$ and $\mathrm{EC}$ in groundwater 

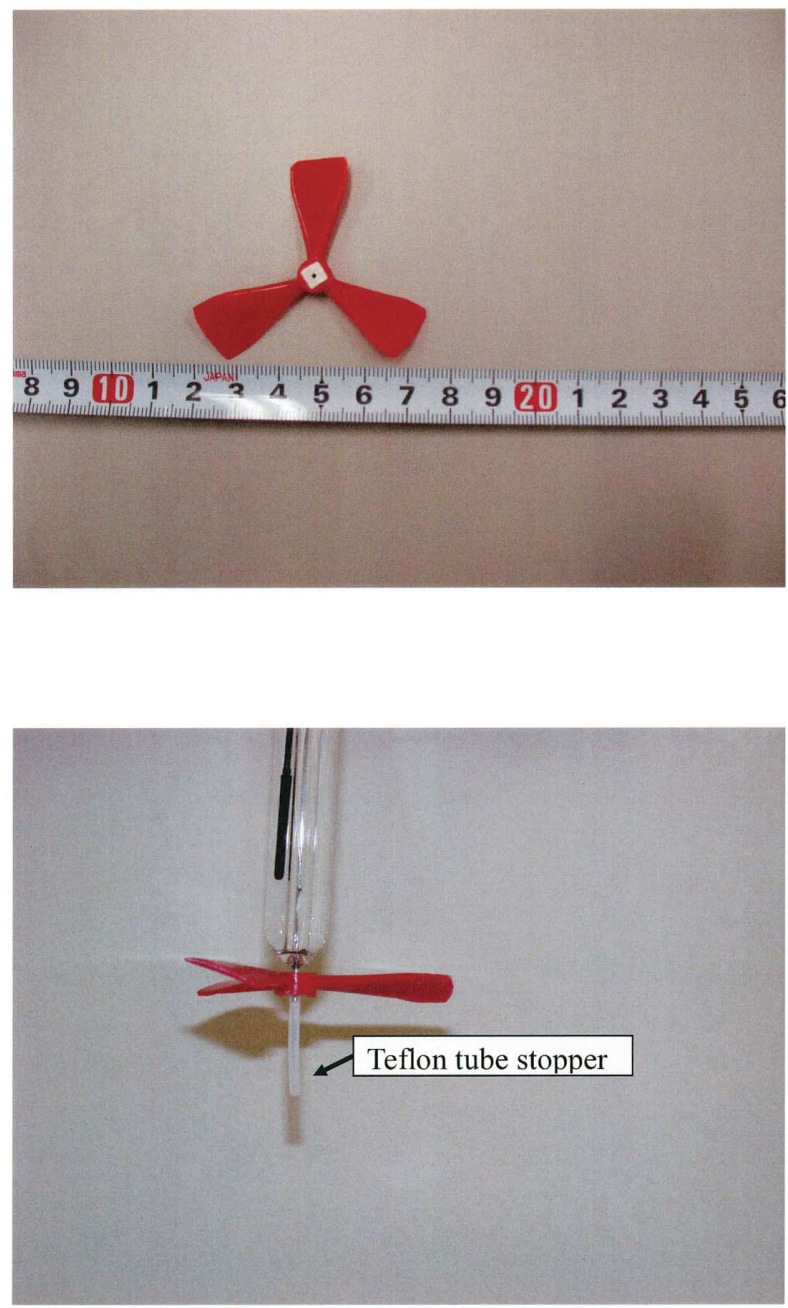

Fig. 2 Photographs of polishing tool for the electrode surface

研磨を不連続で実施した結果, 安定した Eh の值は得られ ていない. 結果として, 地下水の $\mathrm{Eh}$ の測定結果について 不確実性が残ると考えられる。

したがって，本研究では Eh 測定用の白金電極表面の物 理的研磨を連続的に実施して, 水溶液において安定した Eh を得ることが可能か否かの検証, 更に連続的な研磨を 実施しながら Eh を測定する場合と連続的な研磨なしで Eh を測定する場合とを比較し, Eh 測定における連続的研 磨の影響を明らかにすることを目的とする。

\section{2 実験}

実験用に調整した水溶液は, $\mathrm{Na}_{2} \mathrm{~S} \cdot 9 \mathrm{H}_{2} \mathrm{O}$ を使用した $\mathrm{S}^{2-}$ 濃度が $0.05 \mathrm{mM}$ と $0.5 \mathrm{mM}$ の水溶液である. 水溶液は, $1 \mathrm{mM}$ の $\mathrm{Na}_{2} \mathrm{~B}_{4} \mathrm{O}_{7}$ と $1 \mathrm{mM}$ の $\mathrm{H}_{2} \mathrm{SO}_{4}$ を用いて $\mathrm{pH}$ が約 8 になるように調整した。一回の実験に使用した水溶液量は $500 \mathrm{ml}$ である。著者らが調査及び研究を実施している東 濃地域の地下深部の地下水では, 硫黄系の酸化還元反応が
卓越していることが示唆されている ${ }^{13)}$. 本実験に用いた水 溶液 $\left(\mathrm{S}^{2-}: 0.05 \mathrm{mM}\right.$ と $\left.0.5 \mathrm{mM}\right)$ は, 実際の地下水環境で の利用を考虑して, 硫黄系の酸化還元化学種を作るため に, 電極反応に関与する電解質として $\mathrm{Na}_{2} \mathrm{~S} \cdot 9 \mathrm{H}_{2} \mathrm{O}$ を使用 して調整した。

実験に用いた酸化還元電位測定用の電極は，堀場製作所 製の棒状白金複合電極（6861-10C）である。使用する白 金電極の性能試験は，硫酸アンモニウム鉄(II) 六水和物と 硫酸アンモニウム鉄 (III) 12 水和物を純水に溶解し， 2 価 鉄及び 3 価鉄のモル濃度が同じになるように調整した水 溶液を用いて確認した。実験は室温 $\left(20^{\circ} \mathrm{C}\right)$ で行った.

白金電極表面を研磨するための連続研磨器具は，セラミ ック $\left(\mathrm{Al}_{2} \mathrm{O}_{3}\right)$ で作製し，水溶液をかくはんすることによ り生じる流れにより連続回転させるためにプロペラ型の構 造とした（Fig. 2)。水溶液は，マグネチックスターラー を用いてかくはんした。連続研磨器具の回転数は，1 秒で 約 1 回転である。連続研磨の効果を確認するために連続 研磨がない場合の Eh の測定も行った。連続研磨を行わな い場合は, 測定直前にグローブボックス内で研磨紙（\# 600）を使用して白金電極表面の研磨を 1 回だけ実施し た.

水溶液の $\mathrm{Eh}$ と $\mathrm{pH}$ の測定は, 実際の地下水環境を模擬 して低酸素雾囲気下のグローブボックス中において実施し た。グローブボックス内には $\mathrm{N}_{2}$ ガスを循環させ，酸素濃 度は，グローブボックス中で作業しない場合は $0.1 \sim 0.3$ $\mathrm{ppm}$ 程度, 試料の出し入れ等の作業中は $0.5 \mathrm{ppm}$ 程度に 維持した。

実験中に水溶液中の $\mathrm{Eh}, \mathrm{pH}$ 及び酸化還元化学種であ る $\mathrm{S}^{2-}$ と Total-S の測定を行った． $\mathrm{S}^{2-}$ 濃度は，一定時間ご とに $2.5 \mathrm{ml}$ 採取し, 吸光光度法（HACH 製 DR/2010）で, Total-S 濃度は誘導結合プラズマ発光分析法（島津製 ICPS8000）を使用して分析した。 pH は堀場製作所製のガラス 電極 $\mathrm{pH}$ メーター（D-22）で測定した。 $\mathrm{pH}$ は，中性リン 酸塩 $\mathrm{pH}$ 標準液とホウ酸塩 $\mathrm{pH}$ 標準液を用いて $\mathrm{pH}$ 值の確 認を行った。

$$
3 \text { 結 果 }
$$

\section{$3 \cdot 1$ 低酸素雰囲気下での水溶液の $\mathrm{Eh}$ 測定（連続研磨} あり)

$3 \cdot 1 \cdot 10.05 \mathrm{mM}$ の水溶液 Fig. $3 \mathrm{a}$ に測定結果を示 す. Eh は, 測定開始から 5 分で約 $-0.4 \mathrm{~V}$ に達し，その後 約 $0.02 \mathrm{~V}$ の変動はあるが，安定した值を示している. $\mathrm{pH}$ は, 8.0 から 8.2 の範囲で安定している. $\mathrm{S}^{2-}$ 濃度は実験期 間中減少し続け，開始直後の $0.05 \mathrm{mM}$ から 120 分後には $0.0037 \mathrm{mM}$ まで減少した。Total-S 濃度は実験期間中約 $1 \mathrm{mM}$ を維持していた。

$3 \cdot 1 \cdot 20.5 \mathrm{mM}$ の水溶液 Fig. $3 \mathrm{~b}$ に測定結果を示 


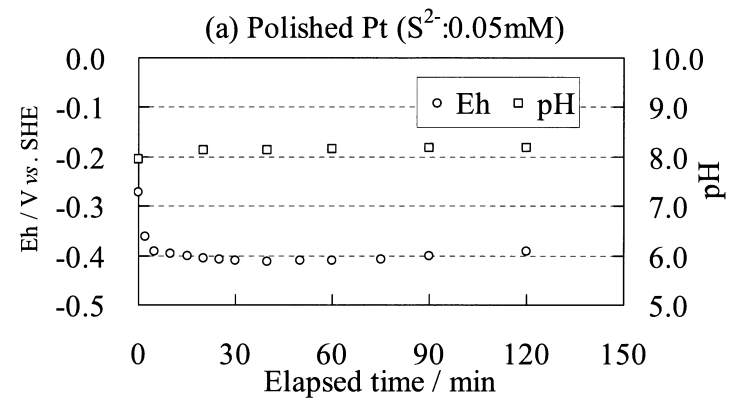

(b) Polished Pt $\left(\mathrm{S}^{2-}: 0.5 \mathrm{mM}\right)$

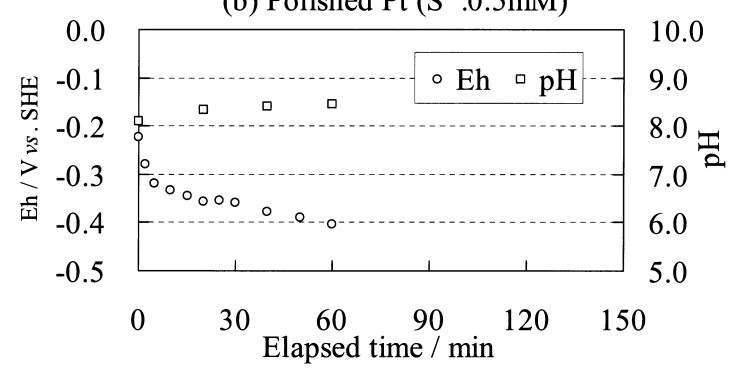

Fig. 3 Eh and $\mathrm{pH}$ values measured with continuous polishing

す. Eh は実験中低下し続け，実験開始直後約 $-0.22 \mathrm{~V}$ で あったのが 60 分後に約 $-0.4 \mathrm{~V}$ の值に達した. $\mathrm{pH}$ も実験 中安定せず上昇し続け，実験開始直後の 8.0 から 60 分後 には 8.5 になった。この溶液において測定された $\mathrm{Eh} の$ 変 動は, $\mathrm{pH}$ の変動に依存している可能性がある. $\mathrm{S}^{2-}$ 濃度 は $0.05 \mathrm{mM}$ の $\mathrm{S}^{2-}$ 濃度の場合と同様に減少し続け, 約 0.5 $\mathrm{mM}$ から 60 分後では $0.24 \mathrm{mM}$ まで減少した。

\section{$3 \cdot 2$ 低酸素雰囲気下での水溶液の $\mathrm{Eh}$ 測定（連続研磨 なし）}

3・2・1 $0.05 \mathrm{mM}$ の水溶液 Fig. 4a に測定結果を示 す. Eh は，実験開始直後は約 $-0.3 \mathrm{~V}$ の值を示したが，す ぐに上昇し, 約 $0.02 \mathrm{~V}$ の変動をしながら $-0.2 \mathrm{~V}$ の值で安 定した. $\mathrm{pH}$ は, 8.0 から 8.2 の範囲で安定している. $\mathrm{S}^{2-}$ 濃度は減少し続け, 開始直後の $0.05 \mathrm{mM}$ から 120 分後に は $0.0065 \mathrm{mM}$ まで減少した。 Total-S 濃度は, 実験期間中 約 $1 \mathrm{mM}$ を維持していた。

3・2・2 $0.5 \mathrm{mM}$ の水溶液 Fig. $4 \mathrm{~b}$ に測定結果を示 す. Eh は, 測定開始 2 分後に約 $-0.27 \mathrm{~V}$ の值を示すが, その後上昇して約 $-0.2 \mathrm{~V}$ の值で安定した。 $\mathrm{pH}$ は, 実験 開始直後の 8.0 から 60 分後に 8.4 にまで上昇した. $\mathrm{S}^{2-}$ 濃 度は減少し, 開始直後の $0.5 \mathrm{mM}$ から 60 分後の $0.21 \mathrm{mM}$ まで減少した。Total-S 濃度は実験開始直後の約 $2 \mathrm{mM}$ か ら $1.5 \mathrm{mM}$ まで減少した. (a) Untreated $\operatorname{Pt}\left(\mathrm{S}^{2-}: 0.05 \mathrm{mM}\right)$

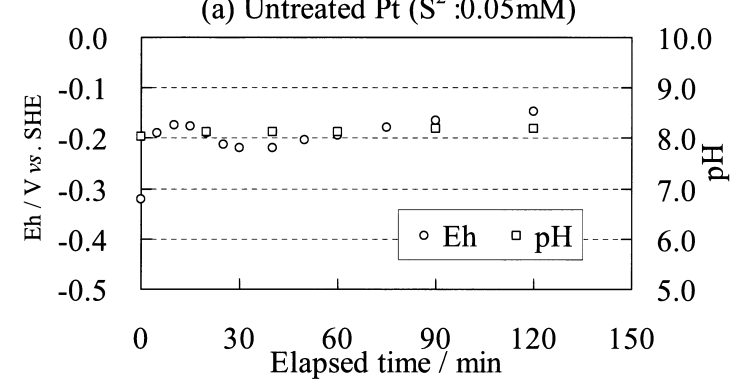

(b) Untreated $\mathrm{Pt}\left(\mathrm{S}^{2-}: 0.5 \mathrm{mM}\right)$

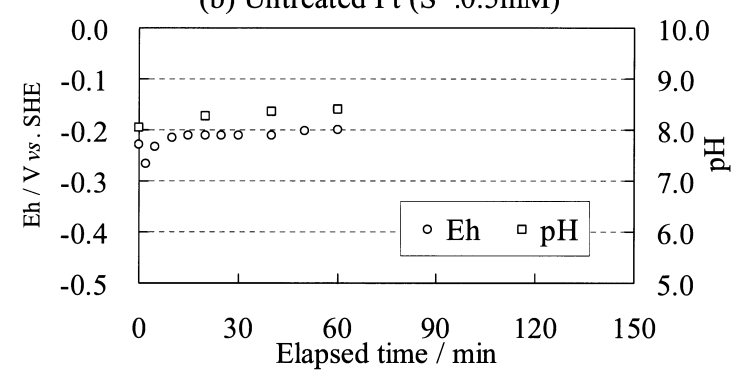

Fig. 4 Eh and $\mathrm{pH}$ values measured without continuous polishing

\section{$4 \cdot 1$ 連続研磨ありで得られた Eh}

測定で得られた水溶液の $\mathrm{Eh}$ 值が表している状態を考察 するために，Eh-pH ダイアグラム ${ }^{14)}$ (Fig. 5) に，セラ ミック研磨器具により連続研磨して得られた Eh と連続研 磨なしで得られた Eh の測定開始から測定終了までの変化 をプロットした。その結果, 連続研磨を実施しながら得ら れた Eh は, 最初の Eh は高く, その後減少する傾向が確 認された。更に 2 種類の水溶液において連続研磨して得 られた $\mathrm{Eh}$ は, $\mathrm{S}_{4}{ }^{2-}-\mathrm{HS}^{-}$の境界線上に位置することから， 以下の式 (1) の平衡関係が成り立っているものと考えら れる。

$$
\mathrm{S}_{4}{ }^{2-}+4 \mathrm{H}^{+}+6 \mathrm{e}^{-}=4 \mathrm{HS}^{-}
$$

2 種類の水溶液 $\left(\mathrm{S}^{2-}: 0.05 \mathrm{mM}\right.$ と $\left.0.5 \mathrm{mM}\right)$ の $\mathrm{Eh}$ を示 した Fig. 3 において, 顕著な Eh の差異が認められないの は, 以下の理由が考えられる. 式 (1) に示した化学反応 式において, 両方向への反応速度が等しい場合（化学平衡 状態), 式 (2) 及び（3）を利用して, 式(1）の平衡時 の $\mathrm{Eh}$ を評価することが可能である ${ }^{14)}$.

$$
\text { pe }=-2.66-2 / 3 \mathrm{pH}-2 / 3 \log \left[\mathrm{HS}^{-}\right]+1 / 6 \log \left[\mathrm{S}_{4}{ }^{2-}\right]
$$

$\mathrm{Eh}=0.059 \mathrm{pe}$ 


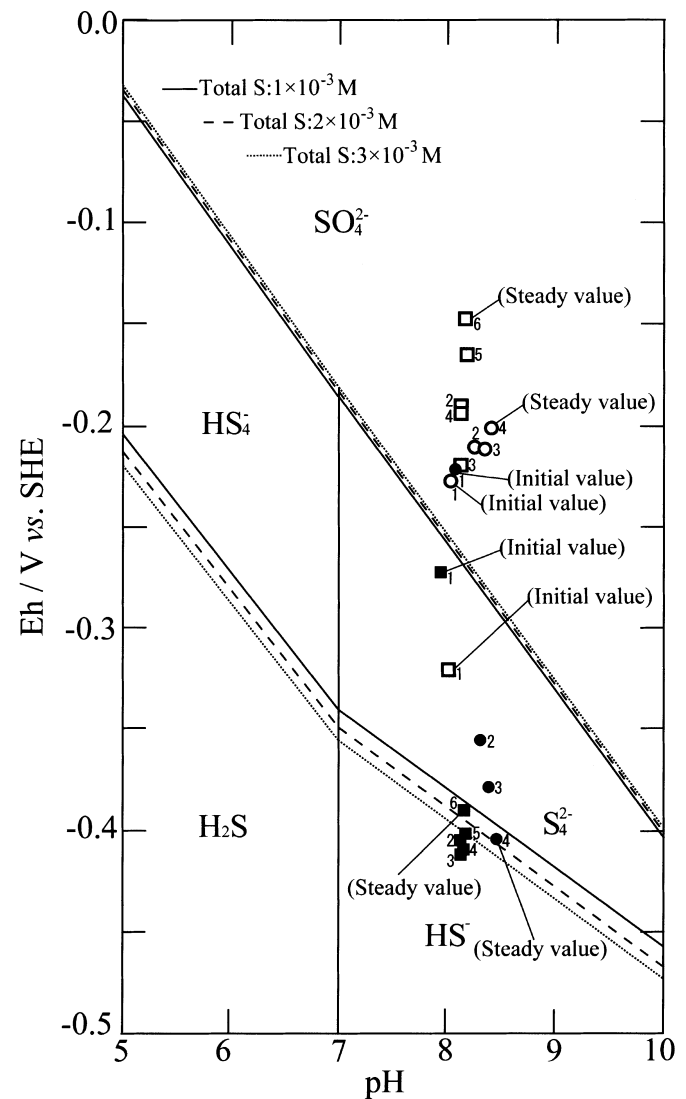

Fig. 5 Eh-pH diagram for the sulphate-sulphide system (for thermodynamics data ${ }^{14)}$ )

口: Polished Pt working electrode (sulphide ion: 0.05 $\mathrm{mM}$ ); : Polished Pt working electrode (sulphide ion: $0.5 \mathrm{mM}$ ); $\square$ : Untreated Pt working electrode (sulphide ion: $0.05 \mathrm{mM}$ ); $\bigcirc$ : Untreated Pt working electrode (sulphide ion: $0.5 \mathrm{mM}$ ); $1,2,3,4,5,6$ : Number of the measurement

しかしながら, 本研究では, $\mathrm{S}_{4}{ }^{2-}$ 濃度の測定を行ってい ないので, 2 種類の溶液中の $\mathrm{S}_{4}{ }^{2-}$ 濃度は明らかでなく, そ のため 2 種類の水溶液の $\mathrm{S}^{2-}$ 濃度に比例して $\mathrm{S}_{4}{ }^{2-}$ が存在し ていない可能性が考えられる. 仮に 10 倍の濃度差を付け て式（2）及び（3）から Ehを評価した場合も，ほとん ど差異は認められない。

硫化物イオン濃度は実験中常に減少していった。これ は, 実験中に $\mathrm{H}_{2} \mathrm{~S}$ の揮発が生じた可能性があるものと考 えられる。

\section{$4 \cdot 2$ 連続研磨なしで得られた Eh}

連続研磨を実施せずに Eh の測定を実施した場合は, 測 定初期に最小の Eh を示し，しだいに上昇する傾向が確認 できた。 セラミック研磨器具による連続研磨なしで得られ た $\mathrm{Eh}$ は, $\mathrm{SO}_{4}{ }^{2-}$ の安定領域にプロットされている（Fig. 5). この理由としては, 硫酸アニオン $\left(\mathrm{HSO}_{4}{ }^{-} \text {や } \mathrm{SO}_{4}{ }^{2-}\right)^{15) 16)}$ や分子状硫黄が白金族電極表面に吸着し, 反応活性を低下
させた結果，電極表面の電気化学的環境が溶液の Eh を反 映していない可能性が挙げられる.

Fig. 4 における 2 種類の水溶液 $\left(\mathrm{S}^{2-}: 0.05 \mathrm{mM}\right.$ と 0.5 $\mathrm{mM})$ の $\mathrm{Eh}$ に顕著な差異が認められないのは，連続研磨 なしで得られた $\mathrm{Eh}$ は，上述したように $\mathrm{SO}_{4}{ }^{2-}$ の安定領域 にプロットされており, $\mathrm{S}^{2-}$ 濃度よりも $\mathrm{SO}_{4}{ }^{2-}$ 濃度が $\mathrm{Eh}$ の 維持に寄与しているためと考えられる.

\section{$4 \cdot 3$ 地下水環境における本手法の適用可能性}

地下水環境では，一つの酸化還元反応だけが認められる ことは少なく, 硫酸還元やメタン生成など, 幾つかの酸化 還元反応が同時に認められる ${ }^{17)}$ 。しかしながら，地下深部 の地下水環境では，鉄あるいは硫黄系が $\mathrm{Eh}$ を支配してい る場合が多いことが明らかになっている ${ }^{18)}$.したがって, そのような地下水環境では，本手法は適用可能であると考 えられる. 今後, 実際の地下水環境において測定を行って いきたい。

$$
5 \text { 結 言 }
$$

低酸素雲囲気下で白金電極表面をセラミック材質のプロ ペラ型研磨器具を用いて連続的に物理研磨しながら測定す ることにより，水溶液中の安定した Eh を迅速に得ること ができることが明らかになった．このことから，白金電極 表面の連続的研磨は, 電極表面への電気化学的に活性ある いは不活性な物質の吸着等を防ぎ，電極一溶液間の電気化 学的環境の変化に対し有効な手段になる可能性が示唆され た.

本研究で使用した水溶液中の酸化還元化学種の濃度は, 東濃地域において採取された地下水の分析結果の範囲内で あり, 硫黄の化学種の酸化還元反応により地下水の $\mathrm{Eh}$ が 決まっている自然条件下の地下水において本研究の結果が 適用可能であると考えられる.

\section{文献}

1) I. Grenthe, W. Stumm, M. Laaksharju, A-C. Nilsson, P. Wikberg: Chem. Geol., 98, 131 (1992).

2) M. Gascoyne: Appl. Geochem., 19, 519 (2004).

3) T. H. Christensen, P. L. Bjerg, S. A. Banwart, R. Jakobsen, G. Heron, H. J. Alberchtsen: J. Contam. Hydrol., 45, 165 (2000).

4) J. G. Morris, W. Stumm: Adv. Chem. Ser., 67, 270 (1967).

5) R. D. Lindberg, D. D. Runnels: Science, 225, 925 (1984).

6) M. Whitfield: Limnol. Oceanogr., 19, 857 (1974).

7) S. Peiffer, O. Klemm, K. Pecher, R. Hollerung: $J$. Contam. Hydrol., 10, 1 (1992).

8) A. Stafánsson, S. Arnórsson, Á. E. Sveinbjörnsdóttir : Chem. Geol., 221, 289 (2005).

9) F. H. Chapelle, P. B. McMahon, N. M. Durbrovsky, R. F. Fujii, E. T. Oaksford, D. A. Vroblesky: Water 
Resour. Res., 31, 359 (1995).

10) H. Ii, Y. Horie, T. Ishii, J. Shimada: Environ. Geol., 32, 17 (1997).

11) 岩月輝希, 豊嶋賢治, 吉田英一: 原子力バックエン ド研究, 4, 73 (1998).

12) C. Degueldre, F. Rochiccioli, A. Laube: Anal. Chim. Acta, 396, 23 (1999).

13) T. Iwatsuki, R. Arthur, K. Ota, R. Metcalfe: Radiochim. Acta, 92, 789 (2004).

14) F. M. M. Morel, J. G. Hering: "Principles and Applications of Aquatic Chemistry”, (1993), (John Wiley
\& Sons, Inc).

15) K. Kunimatsu, M. G. Samant, M. R. Philpott: J. Electroanal. Chem., 243, 203 (1988).

16) 星永 宏: 表面科学, 25, 76 (2004)

17) F. H. Chapelle, S. K. Haack, P. Adraens, M. A. Henry, P. M. Bradley: Environ. Sci. Technol., 30, 3565 (1996).

18) 核燃料サイクル開発機構: “わが国における高レベ 儿放射性廃棄物地層処分の技術的信頼性一地層処分 研究開発第 2 次取りまとめ一分冊 1 わが国の地質 環境”, (1999).

\title{
Stable Measurement of Redox Potential of Aqueous Solution Using Platinum Electrode with Continuous Polishing Tool
}

\author{
Seiichiro IOKA $^{1}$, Teruki IwATsukI ${ }^{1}$, Osamu KATO ${ }^{2}$ and Tsuyoshi Imakita ${ }^{3}$
}

${ }^{1}$ Tono Geoscientific Research Unit, Geological Isolation Research and Development Directorate, Japan Atomic Energy Agency, 1-64, Yamanouchi, Akeyo-cho, Mizunami-shi, Gifu 509-6132

${ }^{2}$ Engineering Department, Engineering Division Nuclear Systems Center, Machinery \& Engineering Company, Kobe Steel, LTD., 4- 2 - 7, Iwayanakamachi, Nada-ku, Kobe-shi, Hyogo 657-0845

${ }^{3}$ Technology Department, Environment \& Chemistry Division, Kobelco Research Institute, INC., 1-5-5, Takatsukuadai, Nishi-ku, Kobe-shi, Hyogo 651 - 2271

(Received 1 May 2006, Accepted 11 July 2006)

A performance test for a redox potential measurement of a solution was conducted using continuously polished and untreated platinum working electrodes under an inert condition. The redox potential, measured by a polished electrode, immediately showed steady value which approximately coincided with the equilibrium value of redox reaction between $\mathrm{HS}^{-}$and $\mathrm{S}_{4}{ }^{2-}$. Thus, the redox potentials could be controlled by the equilibrium of the redox reaction. On the other hand, the redox potential measured by an untreated electrode was $+0.2 \mathrm{~V}$ higher than that measured by a continuously polished electrode. The measured redox potential implies that $\mathrm{SO}_{4}{ }^{2-}$ was the dominant species in the solution. A disagreement of the redox potentials measured by polished and untreated electrodes may have been caused by deactivation of the platinum electrode by the adsorption of sulfuric acid anions.

Keywords : solution; redox potential; platinum electrode; continuous polishing. 